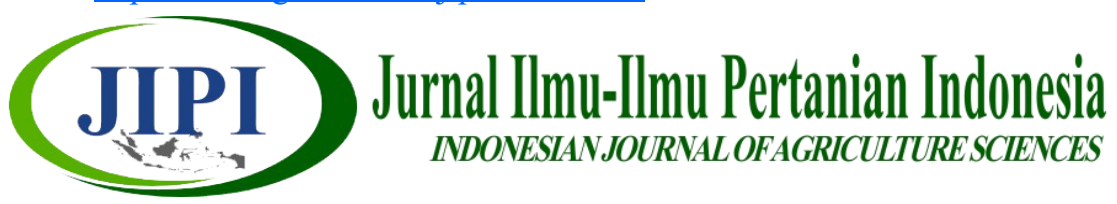

\title{
PENGARUH DOSIS PUPUK KANDANG KAMBING DAN NPK 16:16:16 TERHADAP PERTUMBUHAN DAN KUALITAS JAMBU BIJI KRISTAL (Psidium guajava L.) PADA MUSIM PENGHUJAN
}

\author{
Ariya Listari ${ }^{1}$, Supanjani ${ }^{1 *}$, Sumardi ${ }^{1}$, Widodo $^{1}$, Djamilah $^{2}$ \\ ${ }^{1}$ Program Studi Agroekoteknologi, Fakultas Pertanian Universitas Bengkulu \\ ${ }^{2}$ Program Studi Proteksi Tanaman, Fakultas Pertanian Universitas Bengkulu \\ * Corresponding Author : supanjani@unib.ac.id
}

\begin{abstract}
[THE EFFECT OF GOAT MANURES AND NPK 16:16:16 FERTILIZER ON THE GROWTH OF SEEDLESS GUAVA CROPS AND QUALITY OF ITS FRUIT (Psidium guajava L) AT RAINY SEASONS OF INDONESIA]. Guava var. Crystal, known as seedless guava, is one of the most popular guavas in Indonesia. Compared to other guavas, seedless guava has a softer texture, tastes sweeter, and has fewer seeds. This experiment was carried out from September 2017 to February 2018 at Harapan Makmur village, Pondok Kubang regency, and Central Bengkulu district. The objective of this experiment was to evaluate the effect of goat manure and NPK 16:16:16 fertilizers on the growth of guava crops and the quality of its fruits. The experiment was arranged in a randomized complete block design ( 2 factors, five replications). The first factor tested was the dose of goat manures, consisting of 3 levels: 0,9 , and $18 \mathrm{~kg} / \mathrm{plant}$. The second factor tested was the dose of NPK 16:16:16 fertilizers, consisting of 3 levels: 0, 0,25, and $0.5 \mathrm{~kg} / \mathrm{plant}$. The results showed that goat manures significantly affected the diameter and number of branches. Also, the dose of NPK significantly affected the diameter of branches, degree of leaf greenness, number of flowers, and number of aborted flowers. Finally, the interaction between goat manures and NPK manures did not significantly affect all variables measured, except for leaf areas.
\end{abstract}

Keyword: seedless guava, goat manures, NPK fertilizer

\begin{abstract}
ABSTRAK
Jambu merupakan salah satu produk hortikultura yang berkembang di Indonesia termasuk di Provinsi Bengkulu. Varietas jambu biji kristal merupakan salah satu varietas dari jambu yang belum banyak diketahui oleh masyarakat umum. Jambu biji kristal memiliki berbagai kelebihan di antaranya rasa yang manis, buah yang lunak dan jumlah biji yang sedikit dibandingkan jambu biji lainnya. Penelitian ini dilaksanakan sejak bulan September 2017 sampai dengan bulan Februari 2018 di Desa Harapan Makmur, Kecamatan Pondok Kubang, Kabupaten Bengkulu Tengah. Tujuan penelitian ini adalah untuk mendapatkan dosis pupuk organik dan anorganik yang tepat untuk pertumbuhan dan hasil jambu biji kristal. Penelitian ini menggunakan Rancangan Acak Kelompok Lengkap (RAKL) pola faktorial. Faktor yang diuji yaitu dosis pupuk kandang kambing dan pupuk NPK. Faktor dosis pupuk kandang kambing teridiri atas tiga taraf yaitu $0 \mathrm{~kg} /$ tanaman, $9 \mathrm{~kg} /$ tanaman, dan $18 \mathrm{~kg} /$ tanaman. Faktor kedua tiga taraf dosis pupuk NPK Mutiara 16:16:16 yaitu $0 \mathrm{~kg} / \operatorname{tanaman}, 0,25 \mathrm{~kg} / \tan a m a n$, dan $0,5 \mathrm{~kg} /$ tanaman. Hasil penelitian menunjukkan bahwa dosis pupuk kandang kambing secara statistik berpengaruh nyata $(\mathrm{P} \leq 0,05)$ terhadap diameter cabang dan jumlah cabang. Sedangkan dosis pupuk NPK berpengaruh nyata $(\mathrm{P} \leq 0,05)$ terhadap diameter cabang, jumlah bunga gugur, kehijauan daun, jumlah bunga dan kemanisan buah. Interaksi dosis pupuk kandang kambing dan dosis pupuk NPK nyata pengaruhnya hanya pada variabel luas daun.
\end{abstract}

Kata kunci: jambu biji kristal, pupuk kandang kambing, pupuk NPK 


\section{PENDAHULUAN}

Buah jambu biji merupakan salah satu komoditas dari hortikultura yang masih sangat berpeluang untuk dibudidayakan dan dikembangkan di Indonesia. Ketersediaan jambu biji dalam hal ini akan menjadi nyata dan dirasa oleh masyarakat jika dikelola dengan baik. Untuk mencapai hasil yang sesuai diinginkan, maka perlu memperhatikan aspek di antaranya budidaya, pengolahan, maupun pemasarannya (Rosandi, 2007).

Jambu biji memiliki beberapa varietas unggulan, salah satunya yaitu Jambu Biji Kristal yang memiliki potensi tinggi untuk diusahakan karena mudah dibudidayakan, frekuensi panen yang tinggi, serta belum banyak dibudidayakan (Pakpahan, 2015). Jambu Biji Kristal memiliki jumlah biji yang sedikit dibandingkan dengan varietas lainnya sehingga persentase daging buah lebih besar. Buah Jambu Biji Kristal ini juga bermanfaat bagi kesehatan karena tingginya kandungan vitamin dan serat.

Produksi buah jambu biji di Indonesia khususnya di Provinsi Bengkulu masih sangat rendah yaitu berkisar 1.273 ton/tahun sedangkan di Provinsi Sumatera Utara mencapai 20.716 ton/tahun, 75.455 ton/tahun di Provinsi Jawa Barat, dan 16.817 ton/tahun di Provinsi Nusa Tenggara Timur (BPS, 2015).

Jambu biji dapat tumbuh pada daerah tropik dataran rendah pada ketinggian 1-500 $\mathrm{m}$ di atas permukaan laut. Tanaman jambu biji dapat tumbuh pada suhu antara $15-45{ }^{\circ} \mathrm{C}$, namun hasil terbaik diperoleh pada suhu $23-28{ }^{\circ} \mathrm{C}$ (Ashari, 1995). Curah hujan optimum bagi pertumbuhan tanaman jambu biji berkisar antara 1000-2000 $\mathrm{mm}$ per tahun dengan kelembaban udara 30-50\% (Balitbu, 2014). Sedangkan ketinggian ideal untuk pertumbuhan tanaman jambu biji adalah 1-700 $\mathrm{m}$ di atas permukaan laut (Cahyono, 2010).

Tanaman jambu dapat tumbuh dengan baik pada tanah subur, yaitu apabila unsur-unsur hara dalam tanah tersedia untuk memenuhi kebutuhan. Pemupukan merupakan salah satu cara dalam meningkatkan hasil dan kualitas buah. Hal ini mengingat bahwa jumlah dan kualitas buah merupakan salah satu faktor yang memiliki sifat kompleks sebagai hasil penilaian berdasarkan berbagai sifat seperti ukuran, penerimaan, kesenangan (preferensi) dan nilai gizi. Buah-buahan dipasarkan secara internasional sehingga adanya suatu standar kualitas internasional bagi suatu komoditi sangat diperlukan (Rismunandar, 1980).

Pupuk diberikan pada tanaman untuk meningkatkan unsur-unsur kesuburan tanah dan agar pertumbuhan dan kualitas tanaman meningkat. Pupuk dapat berupa bahan organik dan bahan anorganik yang dapat diberikan sesuai kebutuhan (Lestari, 2009). Pupuk organik diketahui banyak dimanfaatkan sebagai pupuk dalam sistem usaha tani. Pupuk organik adalah pupuk yang tersusun dari materi makhluk hidup, seperti sisa-sia pelapukan tanaman, hewan, dan manusia. Pupuk organik juga dapat memperbaiki sifat fisik tanah melalui pembentukan struktur dan agregat tanah yang mantap dan berkaitan erat dengan kemampuan tanah mengikat air, infiltrasi air, mengurangi resiko terhadap ancaman erosi, meningkatkan kapasitas pertukaran ion dan sebagai pengatur suhu tanah yang semuanya berpengaruh baik terhadap pertumbuhan tanaman (Erfandi et al., 2004 ; Kononova, 1999).

Pupuk anorganik adalah pupuk yang dibuat atau disintesis dari bahan-bahan anorganik di pabrikpabrik. Pupuk anorganik biasanya memiliki kandungan hara yang cukup tinggi dan efek yang ditimbulkan apabila diaplikasikan terhadap tanaman akan tampak lebih cepat. Salah satu jenis pupuk anorganik yaitu Pupuk majemuk NPK. Pupuk majemuk NPK berpengaruh dalam mengoptimalkan dari segi pertumbuhan tanaman. Peranan hara $\mathrm{N}$ dalam memacu pertumbuhan vegetatif dan sintesa asam amino, Kalium yang berfungsi untuk perkembangan akar, pembentukan karbohidrat, serta mempengaruhi penyerapan unsur lainnya, Fosfat yang berperan dalam pembelahan sel, pembentukan bunga dan biji, penyimpanan RNA dan DNA, serta memindahkan energi ATP dan ADP (Idris et.al., 2008).

Beberapa hasil penelitian menunjukkan bahwa pemberian kombinasi pupuk organik dan anorganik merupakan perlakuan yang paling efektif untuk meningkatkan jumlah buah. Penelitian Mahmoud et al. (2009) menunjukkan bahwa pemberian kombinasi pupuk organik dan anorganik dapat meningkatkan pertumbuhan tanaman, hasil, kualitas dan kesuburan tanah. Begitu juga dengan hasil penelitian Suge et al. (2011) yang menunjukkan bahwa pemberian pupuk organik dan anorganik dapat meningkatkan pertumbuhan dan hasil kualitas buah terong. Pemberian pupuk organik dan pupuk anorganik pada tanaman tomat lebih baik, dibandingkan dengan hanya pemberian salah satu pupuk organik atau pupuk anorganik saja (Ogbomo, 2011). Memperhatikan hasil-hasil penelitian di atas, kombinasi pemupukan organik dan anorganik merupakan perlakuan yang paling efektif untuk mencapai hasil yang optimal dalam budidaya Jambu Biji Kristal. Oleh karena itu perlu dilakukan penelitian tentang pengaruh pupuk organik (pupuk kandang kambing) dan anorganik (NPK) terhadap pertumbuhan dan kualitas Jambu Biji Kristal.

Penelitian ini bertujuan untuk mendapatkan dosis pupuk organik dan anorganik serta interaksi yang terbaik untuk pertumbuhan dan hasil Jambu Biji Kristal.

\section{METODE PENELITIAN}

Penelitian ini dilaksanakan sejak bulan September 2017 sampai dengan Februari 2018, bertempat di Desa Harapan Makmur, Kecamatan Pondok Kubang, Kabupaten Bengkulu Tengah.

Penelitian menggunakan pola faktorial dua faktor, dengan masing-masing faktor terdiri atas tiga taraf, 
yang disusun dalam Rancangan Acak Kelompok Lengkap (RAKL) dengan empat ulangan. Faktor pertama pupuk kandang kambing berturut-turut 0 $\mathrm{kg} /$ tanaman, $9 \mathrm{~kg} / \operatorname{tanaman}$, dan $18 \mathrm{~kg} /$ tanaman. Faktor kedua pupuk NPK majemuk 16:16:16 yaitu $0 \mathrm{~kg} /$ tanaman, $0,25 \mathrm{~kg} / \operatorname{tanaman}$, dan $0,5 \mathrm{~kg} /$ tanaman.

Penelitian ini menggunakan tanaman Jambu Kristal dengan jarak tanam $3 \mathrm{~m}$ x $3 \mathrm{~m}$ dengan umur tanaman 1 tahun 8 bulan. Kriteria pemilihan sampel tanaman Jambu Biji Kristal yaitu tinggi tanaman telah mencapai $1,5 \mathrm{~m}$, dan banyak terdapat cabang. Cabang sampel dipilih sebanyak 5 cabang yang memenuhi kriteria : seluruh cabang vegetatif (yang belum berbunga), panjang cabang $\pm 60 \mathrm{~cm}$, dan diameter $\pm 0,5-1 \mathrm{~cm}$, posisi cabang sampel $45^{\circ}$ atau terletak di atas (terkena sinar matahari), dan cabang tidak tumbuh tegak lurus $90^{\circ}$.

Buah dipanen ketika buah mencapai ukuran bola kasti, berwarna kuning $>50 \%$ (hijau kekuningan atau keputihan). Panen buah dilakukan setiap 4 hari sekali dan ada juga yang dipanen setiap satu minggu satu kali, dengan cara manual menggunakan gunting panen buah.

Pengamatan dilakukan terhadap variabel vegetatif dan variabel generatif. Data dari hasil pengamatan dianalisis secara statistik menggunakan Analysis of Variance (ANOVA) atau uji $F$ pada taraf $5 \%$. Perbandingan rata-rata antar perlakuan dilakukan dengan DMRT pada taraf 5\% (Gomez \& Gomez, 1984).

\section{HASIL DAN PEMBAHASAN}

Penelitian dilaksanakan pada bulan September 2017 - Februari 2018 di Desa Harapan Makmur, Kecamatan Pondok Kubang, Kabupaten Bengkulu Tengah. Lokasi penelitian memiliki kelembaban udara berkisar antar 80-87\%, suhu udara maksimum $29,6{ }^{\circ} \mathrm{C}-31,5^{\circ} \mathrm{C}$ dan suhu minimum $23,1{ }^{\circ} \mathrm{C}-24,2^{\circ} \mathrm{C}$. Berdasarkan klasifikasi iklim Kabupaten Bengkulu Tengah tergolong iklim A (tropis basah) dengan curah hujan tahunan $2.626 \mathrm{~mm}$ sedangkan bulanan $230 \mathrm{~mm}-620 \mathrm{~mm}$. Jumlah bulan basah 10 bulan dimulai dari bulan Oktober hingga bulan Juli dan jumlah hari hujan berkisar 10 hari -23 hari. Tanaman Jambu Biji Kristal ini terdiri dari 36 tanaman dengan umur tanaman 1 tahun 8 bulan dan sudah pernah panen satu kali musim panen.

Secara umum tanaman Jambu Biji Kristal tumbuh dengan baik di lokasi penelitian. Saat penelitian, tanaman dan buah Jambu Biji Kristal terserang hama dan penyakit. Hama yang menyerang pada tanaman dan buah yaitu ulat bulu, lalat buah, semut, belalang dan kutu putih. Sedangkan penyakit yang menyerang antara lain busuk buah.

Hasil analisis data menunjukkan bahwa dosis pupuk kandang kambing secara statistik berpengaruh nyata $(\mathrm{P} \leq 0,05)$ terhadap diameter cabang dan jumlah cabang. Namun pemberian dosis pupuk kandang kambing berpengaruh tidak nyata $(\mathrm{P}>0,05)$ terhadap jumlah daun, jumlah cabang produktif, jumlah bunga gugur, kehijauan daun, luas daun, jumlah bunga, jumlah bakal buah, jumlah bakal buah satu pohon, diameter buah, bobot buah, jumlah buah, dan kemanisan buah. Sedangkan dosis pupuk NPK berpengaruh nyata $(\mathrm{P} \leq 0,05)$ terhadap diameter cabang, jumlah bunga gugur, kehijauan daun, jumlah bunga dan kemanisan buah. Namun pemberian pupuk NPK berpengaruh tidak nyata $(\mathrm{P}>0,05)$ terhadap jumlah daun, jumlah cabang, jumlah cabang produktif, luas daun, jumlah bakal buah, jumlah bakal buah satu pohon, diameter buah, bobot buah dan jumlah buah.

Interaksi dosis pupuk kandang kambing dan dosis pupuk NPK nyata pengaruhnya hanya pada variabel luas daun. Luas daun terbesar diperoleh dengan pemberian dosis pupuk kandang kambing $18 \mathrm{~kg} /$ tanaman dan pupuk NPK $0 \mathrm{~kg} / \operatorname{tanaman}$ yaitu $57,7 \mathrm{~cm}^{2}$. Luas daun terkecil yaitu $41,8 \mathrm{~cm}^{2}$ dihasilkan oleh dosis pupuk kandang kambing $0 \mathrm{~kg} /$ tanaman dan pupuk NPK 0 kg/tanaman (Gambar 1).

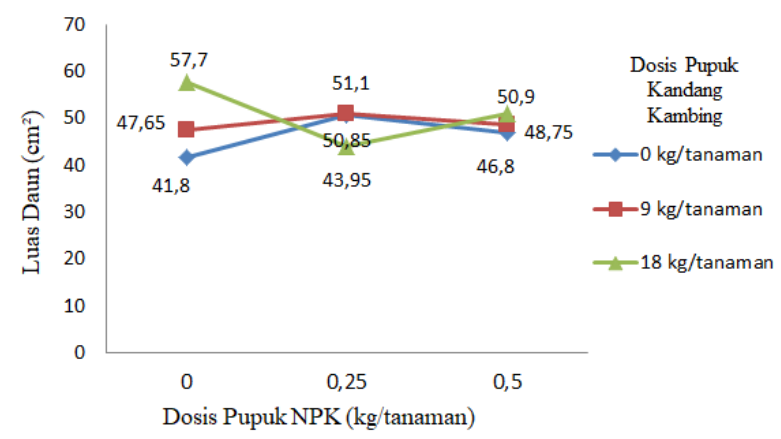

Gambar 1. Interaksi pemberian pupuk kandang kambing dan pupuk NPK majemuk 16:16:16 terhadap Luas Daun

Bertambah dan berkurangnya luas daun disebabkan adanya persaingan antar daun dalam merebut intensitas matahari sebagai sumber fotosintesis dan adanya kompetisi asimilat antar organ sink yang mengakibatkan luas daun tumbuh tidak sama (Wirianita et al., 2018). Luas daun juga dipengaruhi oleh jumlah daun, semakin banyak jumlah daun semakin besar nilai luas daun. Luas daun yang besar dapat menghasilkan asimilat yang lebih banyak, sebaliknya luas daun yang rendah maka asimilat yang dihasilkan lebih sedikit (Salisbury \& Ross, 1985). Proses fotosintesis akan optimal apabila luas daun semakin besar yang pada gilirannya asimilat yang dihasilkan lebih banyak sehingga produktivitas tanaman semakin meningkat.

Dosis pupuk kandang kambing 9 kgtanaman menghasilkan pertambahan diameter cabang terbesar rata-rata $0,40 \mathrm{~mm}$ dan pertambahan jumlah tunas/ cabang terkecil rata-rata 1,86 . Dosis pupuk kandang kambing $0 \mathrm{~kg} /$ tanaman menghasilkan pertambahan diameter cabang dan jumlah tunas/cabang yang secara statistik tidak berbeda dengan yang dihasilkan dosis 
$18 \mathrm{~kg} /$ tanaman. Diameter cabang yang cenderung kecil pada tanaman dapat disebabkan terjadinya kompetisi asimilat antar cabang atau organ sink. Kemampuan kompetitif organ sink untuk menarik asimilat berbedabeda, sink yang kuat akan mendapatkan bagian asimilat lebih cepat dan lebih banyak dibandingkan dengan sink yang lemah (Purnamawati \& Manshuri, 2015) (Tabel 1).

Tabel 1. Pengaruh dosis pupuk kandang kambing terhadap pertambahan diameter cabang dan jumlah cabang

\begin{tabular}{ccc}
\hline $\begin{array}{c}\text { Dosis Pupuk Kandang } \\
\text { Kambing }\end{array}$ & $\begin{array}{c}\text { Pertambahan } \\
\text { diameter cabang } \\
(\mathrm{mm})\end{array}$ & $\begin{array}{c}\text { Pertambahan } \\
\text { jumlah tunas/ } \\
\text { cabang }\end{array}$ \\
\hline $0 \mathrm{~kg}$ & $0,30 \mathrm{~b}$ & $2,25 \mathrm{a}$ \\
$9 \mathrm{~kg}$ & $0,40 \mathrm{a}$ & $1,86 \mathrm{~b}$ \\
$18 \mathrm{~kg}$ & $0,35 \mathrm{ab}$ & $2,48 \mathrm{a}$
\end{tabular}

Keterangan : Rata-rata yang diikuti oleh huruf yang sama pada kolom yang sama berbeda tidak nyata pada DMRT 0.05

Jumlah tunas terbanyak diperoleh dari dosis pupuk kandang kambing $18 \mathrm{~kg} /$ tanaman, namun hasil ini berbeda tidak nyata dengan pemberian dosis pupuk $0 \mathrm{~kg} / \tan a m a n$, sedangkan pemberian dosis pupuk dengan hasil terendah adalah pemberian dosis pupuk $9 \mathrm{~kg} / \mathrm{tanaman}$. Hal ini disebabkan karena jumlah tunas yang tumbuh sangat dipegaruhi juga oleh tunas baru yang tumbuh. Semakin banyak tunas yang tumbuh maka semakin banyak cabang terbentuk, sebaliknya semakin sedikit jumlah tunas maka semakin sedikit jumlah cabang yang tumbuh (Alam, 2017).

Dosis pupuk anorganik NPK majemuk 16:16:16 berpengaruh nyata terhadap variabel diameter cabang, kehijauan daun, jumlah bunga gugur, jumlah bunga dan kemanisan buah jambu biji kristal (Tabel 2).

Tabel 2. Pengaruh dosis pupuk NPK terhadap diameter cabang, kehijauan daun, jumlah bunga, jumlah bunga gugur dan kemanisan buah

\begin{tabular}{cccccc}
\hline $\begin{array}{c}\text { Dosis Pupuk } \\
\text { NPK/tanaman }\end{array}$ & $\begin{array}{c}\text { Pertambahan } \\
\text { diameter } \\
\text { cabang } \\
(\mathrm{cm})\end{array}$ & $\begin{array}{c}\text { Kehijauan } \\
\text { daun }\end{array}$ & $\begin{array}{c}\text { Jumlah } \\
\text { bunga } \\
\text { gugur/ } \\
\text { cabang }\end{array}$ & $\begin{array}{c}\text { Jumlah } \\
\text { bunga } \\
\text { cabang }\end{array}$ & $\begin{array}{c}\text { Kemanisan buah } \\
\text { ('brix) }\end{array}$ \\
\hline $0 \quad \mathrm{~kg}$ & $0,29 \mathrm{~b}$ & $1,65 \mathrm{~b}$ & $2,15 \mathrm{~b}$ & $2,15 \mathrm{~b}$ & $9,18 \mathrm{~b}$ \\
$0,25 \mathrm{~kg}$ & $0,37 \mathrm{a}$ & $1,47 \mathrm{~b}$ & $2,13 \mathrm{~b}$ & $2,13 \mathrm{~b}$ & $9,98 \mathrm{a}$ \\
$0,5 \mathrm{~kg}$ & $0,39 \mathrm{a}$ & $3,24 \mathrm{a}$ & $3,06 \mathrm{a}$ & $3,06 \mathrm{a}$ & $10,13 \mathrm{a}$ \\
\hline
\end{tabular}

Keterangan : Rata-rata yang diikuti oleh huruf yang sama pada kolom yang sama berbeda tidak nyata pada DMRT 0,05

Dosis pupuk NPK majemuk 16:16:16 sebanyak $0,5 \mathrm{~kg} /$ tanaman mampu menghasilkan pertambahan diameter cabang terbesar, kehijauan daun terbesar, jumlah bunga gugur/cabang terbanyak, jumlah bunga/ cabang terbanyak, dan kemanisan buah terbesar. Dosis pupuk anorganik berperan dalam mempengaruhi proses pertumbuhan tanaman jambu biji kristal. Tanaman dengan unsur hara yang cukup akan menunjukkan proses pertumbuhan yang baik (Hadiati et al., 2015).

Warna kulit buah dapat diketahui dengan cara mencocokkan warna kulit buah dengan Munsell Color Chart for Plant. Hasil yang diperoleh menunjukkan warna kulit buah jambu biji kristal yaitu hijau kuning, hijau, dan hijau muda. Warna kulit buah hijau kuning mendominasi pada setiap perlakuan dibandingkan dengan warna lainnya (Tabel 3). Warna kulit jambu biji kristal terdiri atas tiga kriteria yaitu $100 \%$, hijau dan hijau $75 \%$ kuning $25 \%$ (Liliandra, 2015).. Warna terbaik jambu biji kristal yang siap panen adalah berwarna hijau $75 \%$ kuning $25 \%$. Pada jambu biji selama pemasakan buah, kandungan klorofil buah menurun dan karotenoid buah meningkat yang mengakibatkan perubahan warna buah dari hijau menjadi kuning (Jain et al., 2003)

Tabel 3. Warna kulit buah Jambu Kristal pada dosis pupuk kandang kambing dan NPK

\begin{tabular}{ccc}
\hline Perlakuan & Wama & Keterangan \\
\hline N0-K0 & 5 gy $7 / 8$ & Hijau pucat atau Wama Kuning \\
N1-K0 & 5 gy $6 / 10$ & Wama hijau muda \\
N2-K0 & 5 gy $7 / 8$ & Hijau pucat atau Wama Kuning \\
N0-K1 & 5 gy $6 / 10$ & Wama hijau muda \\
N1-K1 & 5 gy $6 / 10$ & Wama hijau muda \\
N2-K1 & 5 gy $7 / 8$ & Hijau pucat atau Wama Kuning \\
N0-K2 & 5 gy $7 / 8$ & Hijau pucat atau Wama Kuning \\
N1-K2 & 5 gy $7 / 6$ & Wama kuning muda \\
N2-K2 & 5 gy $6 / 10$ & Wama hijau muda \\
\hline Keterangan : Analisis warna buah berdsasarkan Munsell Color Chart for Plant. \\
\multicolumn{3}{c}{ Nilai hue 5 gy $7 / 8=$ hijau kuning, 5 gy $6 / 10=$ hijau muda, } \\
& 5 gy $5 / 10=$ hijau.
\end{tabular}

\section{KESIMPULAN}

Berdasarkan hasil penelitian maka dapat disimpukan bahwa dosis pupuk organik terbaik untuk hasil dan pertumbuhan Jambu Biji Kristal yaitu pupuk kandang kambing $18 \mathrm{~kg} /$ tanaman. Dosis pupuk anorganik terbaik untuk hasil dan pertumbuhan Jambu Biji Kristal yaitu pupuk NPK Mutiara 16:16:16 0,5 kg/tanaman. Interaksi antara pupuk organik dan pupuk anorganik hanya terjadi pada luas daun yaitu dengan nilai luas daun tertinggi $57,7 \mathrm{~cm}^{2}$.

\section{DAFTAR PUSTAKA}

Ashari, S. (1995). Hortikultura Aspek Budidaya. UI Press (ID) . Jakarta.

Balai Penelitian Tanaman Buah Tropika. (2014). Budidaya jambu biji. http://hortikultura. litbang. pertanian.go.id/ budidaya-jambu-biji/. Diakses 08 September 2018. [Online]. 
BPS. (2015). Produksi Buah-buahan menurut Kabupaten/Kota dan Jenis Buah di Bengkulu. https:// bengkulu.bps.go.id/statictable/2015/03/27/122/ produksi-buah-buahan-menurut-kabupatenkota-dan-jenis-buah-di-bengkulu-kuintal2015. html. Diakses 25 Agustus 2018. [Online].

Cahyono, B. (2010). Sukses Budi Daya Jambu Biji di Pekarangan dan Perkebunan. Yogyakarta.

Erfandi, D., Kurnia, U. \& Juarsah, I.. (2004). Pemanfaatan Bahan Organik Dalam Perbaikan Sifat Fisik dan Kimia Tanah Ultisol. Prosiding Semnas. Pendayagunaan Tanah Masam, Buku II, Puslitbang Tanah dan Agroklimat, Bogor.

Gomez, K.A. \& Gomez, A.A. (1984). Statistical Procedures for Agricultural Research. John Wiley $\&$ Sons., Singapore.

Hadiati, S., Apriyanti, \& Leni, H. (2015). Bertanaman Jambu Biji di Pekarangan. AgriFlo. Jakarta.

Idris, A.R. (2008). Pengaruh bahan organik dan pupuk NPK terhadap serapan hara dan produksi jagung di Inceptisol Ternate. Jurnal Tanah dan Lingkungan, 10(1), 7-13.

Jain, N., Dhawan, K., Maholtra, S., \& Singh, R. (2003). Biochemistry of fruit ripening of guava (Psidium guajava L.): compositional and enzymatic changes. Plant Foods for Human Nutr, 58, 309-315.

Kononova, M.M. (1999). Soil Organic Matter. Its Role in Soil Formation and Soil Fertility. Vergamon Press. Oxford. London.

Lestari, A.P, (2009). Subtitusi pupuk anorganik dengan kompos sampah kota pada tanaman jagung manis (Zea mays Saccharata Sturt ). Prosiding Semirata BKS PTN Indonesia Wilayah Barat Bidang Ilmu Pertanian. Banten

Liliandra, R. (2015). Pengaruh rasio daun : buah terhadap ukuran dan kualitas buah jambu biji (Psidium guajava. L). Skripsi. Fakultas Pertanian. Institut Pertanian Bogor, Bogor. (tidak dipublikasi)

Mahmoud, E., El- Kader, N.A., Robin, P., Corfini, N.A. \& El- Rahman, L.A. (2009). Effects of different organic and inorganic fertilizers on cucumber yield and some soil properties. World Journal Of Agricultural Sciences, 5(4), 408-414.

Ogbomo, L.K.E. (2011). Comparison of growth, yield performance and profitability of tomato (Solanum lycopersicon) under different fertilizer types in humid forest ultisols. Int. Res. J. Agric. Sci. Soil Sci, 1(8), 332-338.

Pakpahan, T.E. 2015. Kajian tekhnik mencangkok perbanyakan jambu kristal (Prisidium guava). Agrica Ekstensia, 9(2), 27-30.

Purnamawati, H. \& Manshuri, A.G.. (2015). Source dan sink pada tanaman kacang tanah. Balai Penelitian Tanaman Aneka Kacang dan Umbi, Malang.http:// balitkabi.litbang.pertanian.go.id/publikasi/ monografi/inovasi-teknologi-dan-pengembangan -produk-kacang-tanah-2015/. Diakses 29 Agustus 2018. [Online].

Rismunandar. (1980). Syarat tumbuh jambu biji yang tepat. Komoditi Internasional, 6(2), 22-34.

Rosandi, A.W. (2007). Analisis faktor-faktor yang mempengaruhi penawaran ekspor Indonesia. Skripsi. Fakultas Ekonomi dan Manajemen. Institut Pertanian Bogor, Bogor.

Romalasari, A., Susanto, S., Melati, M. \& Junaedi, A. (2017). Perbaikan kualitas jambu biji (Psidium guajava L.) kultivar kristal dengan berbagai warna dan bahan pembrongsongan. J. Hort. Indonesia, 8(3), 155-161.

Salisbury, F.B. \& Ross, C.W. (1992). Fisiologi Tumbuhan. Jilid 2. Terjemahan oleh : Lukman, D.R., dan Sumaryono. ITB, Bandung.

Suge, J.K., Omunyin, M.E. \& Omami, E.N. (2011). Effect of organic and inorganic sources of fertilizer on growth, yield and fruit quality of eggplant (Solanum melongena L). Scholars Research Library, 3(6), 470-479.

Wirianita, Mansyur \& Hana, S. (2018). Studi pengaruh campuran pupuk dengan metode MAC Donald terhadap kematangan kompos J. Presipitasi, 2(1), $1-7$. 